\title{
Occurrence of the pathogenic bacteria Pantoea agglomerans in soybean cultivation
}

\section{Występowanie bakterii fitopatogenicznej Pantoea agglomerans w uprawie soi}

\author{
Wołodymyr Patyka ${ }^{1}$, Tetiana Gnatiuk ${ }^{1}$, Natalia Zhytkevych ${ }^{1}$, \\ Antonina Kalinichenko ${ }^{2}$, Krzysztof Frączek ${ }^{3}$
}

\section{Summary}

The results of monitoring of soybean crops in Ukraine revealed the occurrence of numerous pathogens. Along with the typical and common bacterial diseases of soybean, the facultative plant pathogen Pantoea agglomerans is becoming more active. In some years the pathogen is widespread and damaging, whereas in the others its development was restrained.

Key words: Pantoea agglomerans; phytopathogen; monitoring; biological properties

\section{Streszczenie}

Monitorowanie występowania chorób bakteryjnych w uprawach soi na Ukrainie wykazało różnorodny skład gatunkowy czynników chorobotwórczych. Stwierdzono, że wraz z typowymi i powszechnymi chorobami bakteryjnymi soi aktywizuje się fakultatywny fitopatogen Pantoea agglomerans. W niektórych latach patogen występuje powszechnie i powoduje znaczące straty, w innych latach jego rozwój jest ograniczony.

Słowa kluczowe: Pantoea agglomerans; fitopatogen; monitoring; właściwości biologiczne

\footnotetext{
Instytut Mikrobiologii i Wirusologii im. D.K. Zabołotnogo Państwowej Akademii Nauk Ukrainy 03680, Kijów, Akademika Zabolotnogo 154

${ }^{2}$ Uniwersytet Opolski, Katedra Inżynierii Procesowej Dmowskiego 7-9, 45-365 Opole

${ }^{3}$ Uniwersytet Rolniczy im. Hugona Kołłątaja w Krakowie

Wydział Rolniczo-Ekonomiczny, Katedra Mikrobiologii

Al. Mickiewicza 24/28, 30-058 Kraków

*corresponding author: akalinichenko@uni.opole.pl
} 


\section{Wstęp / Introduction}

Rozprzestrzenianie chorób bakteryjnych soi zależy od czynników klimatycznych i rolno-ekologicznych (Gerhardt 1983). Z badań prowadzonych w ostatnich dziesięcioleciach fitopatolodzy wyciągają wniosek, że w rolnictwie Ukrainy choroby wywoływane przez bakterie są równie ważne jak choroby powodowane przez grzyby (Gorlenko 1966), a nawet w niektórych przypadkach przekraczają poziom ich występowania. Jednocześnie zaobserwowano wzrost porażenia roślin patogenami bakteryjnymi zarówno przez polifagi, jak i monofagi. W tym samym czasie odnotowano wzrost poziomu agresywności mikroorganizmów, które wcześniej były uznawane za fakultatywnie patogeniczne dla roślin (Dankevich i wsp. 2010). Jednym $\mathrm{z}$ takich patogenów jest Pantoea agglomerans, który w ciągu całego okresu wegetacji jest częścią metagenomu populacji rodzimej mikroflory roślin, zwłaszcza bakterii chorobotwórczych. W niektórych przypadkach może powodować porażenie łodygi i ogonków: soi, fasoli, grochu i innych roślin strączkowych. $P$. agglomerans jest też stałym składnikiem ryzosferowej, epifitycznej i endofitycznej mikroflory roślin (Gerhardt 1983; Zhytkevych i Zhmurko 2005). Zasugerowano, że wszystkie żółtopigmentowe objawy bakteriozy roślin uprawnych pochodzą od $P$. agglomerans, co może być spowodowane stopniowym przystosowaniem się jej do pasożytnictwa (Zhytkevych i wsp. 2009).

P. agglomerans może też wpływać na proces zakażenia spowodowany innym fitopatogenem, powodując wówczas ograniczenie objawów chorobowych wywołanych przez tego patogena (Gerhardt 1983). Wyniki badań są zbieżne z danymi dotyczącymi skutków konkurencji między $P$. $a g$ glomerans i czynnikami głównych bakterioz soi (Zhytkevych i Zhmurko 2005). W 2003 roku na Ukrainie (obwód Kijowski) zaobserwowano masowe porażenie łodyg spowodowane przez tego fakultatywnego patogena.

Celem pracy było monitorowanie porażenia upraw soi na Ukrainie przez P. agglomerans oraz zbadanie jego właściwości biologicznych.

\section{Materiały i metody / Materials and methods}

Monitorowanie występowania i rozprzestrzeniania się chorób porażających łodygi soi prowadzono przez okres 10 lat (2003-2013) na polach doświadczalnych oraz w uprawach produkcyjnych. Doświadczenia prowadzono w regionach: Kijowskim, Winnickim, Czerkaskim, Rówieńskim i Chersońskim. Badanie roślin soi oraz izolację patogenu $P$. agglomerans przeprowadzono w fazie od kiełkowania do kwitnienia oraz podczas wypełniania i dojrzewania nasion. Analizę porażenia roślin soi wykonano w warunkach terenowych metodą liniową. Linie wyznaczono prostopadle do krawędzi pola; linia zaczynała się 15 metrów od krawędzi pola. W punktach badawczych (od 3-5) oceniano populację patogenów występującą na różnych częściach roślin lub istnienie objawów choroby (Iwanow 2001).

W doświadczeniach dotyczących patogeniczności $P$. agglomerans obiektem były izolaty bakteryjne (185 szczepów) wyizolowane z uszkodzonych tkanek soi pochodzących $\mathrm{z}$ doświadczeń i upraw produkcyjnych. Wytypowano pędy roślin z objawami uszkodzeń bakteryjnych, które następnie poddano analizie bakteriologicznej.

Właściwości chorobotwórcze wybranych izolatów bakteryjnych określono w warunkach terenowych. W doświadczeniu zastosowano cztery powtórzenia. Sztuczne zakażenie roślin soi (5 roślin dla każdego izolatu) przeprowadzono wstrzykując bakteryjną zawiesinę komórek w ich łodygi i liście. Gęstość zawiesiny wynosiła $1 \times 10^{9} \mathrm{jtk} / \mathrm{cm}^{3}$. Na każdej roślinie iniekcjami zaszczepiono trzy poziomy liści w czterech powtórzeniach na każdym liściu, jak również łodygi i nasiona. Grupą kontrolną było 5 roślin soi, które zaszczepiono sterylną wodą. Odczyt zakażenia sztucznego wykonano po 10-14 dniach w skali 5-punktowej (Patyka i wsp. 2007).

W badaniu właściwości biologicznych jako gatunki testowe wykorzystano 5 szczepów P. agglomerans (tab. 1) oraz Xanthomonas axonopodis pv. glicynes (3 szczepy), uzyskane z kolekcji kultur mikroorganizmów z Działu

Tabela 1. Kolekcyjne szczepy Pantoea agglomerans wykorzystane w badaniach

Table 1. Strains of Pantoea agglomerans - used in the study

\begin{tabular}{l|l|l}
\hline \multirow{2}{*}{$\begin{array}{c}\text { Izolat Pantoea agglomerans } \\
\text { Isolate of Pantoea agglomerans }\end{array}$} & $\begin{array}{c}\text { kraj pochodzenia, } \\
\text { roślina-gospodarz } \\
\text { country of origin host-plant }\end{array}$ & $\begin{array}{c}\text { Pochodekcja } \\
\text { collection }\end{array}$ \\
\cline { 2 - 3 } P. agglomerans 8490 & Szkocja, owies - Scotland, oat & $\begin{array}{l}\text { Wydział fitopatogenicznych bakterii IMW PANU } \\
\text { Department of phytopathogenic bacteria IMVNASU }\end{array}$ \\
\hline P. agglomerans 7695 & Ukraina, fasola - Ukraine, beans & $\begin{array}{l}\text { Wydział fitopatogenicznych bakterii IMW PANU } \\
\text { Department of phytopathogenic bacteria IMVNASU }\end{array}$ \\
\hline P. agglomerans 8456 & Rumunia, fasola - Romania, beans & $\begin{array}{l}\text { Wydział fitopatogenicznych bakterii IMW PANU } \\
\text { Department of phytopathogenic bacteria IMVNASU }\end{array}$ \\
\hline P. agglomerans 8508 & $\begin{array}{l}\text { Południowa Afryka, mango - South } \\
\text { Africa, mango }\end{array}$ & $\begin{array}{l}\text { Wydział fitopatogenicznych bakterii IMW PANU } \\
\text { Department of phytopathogenic bacteria IMVNASU }\end{array}$ \\
\hline P. agglomerans UKM V-1089 & Belgia, owies - Belgium, oat & $\begin{array}{l}\text { Ukrainska Kolekcja Mikroorganizmów (typowy szczep) } \\
\text { Ukrainian colection of microorganisms (typical strain) }\end{array}$ \\
\hline
\end{tabular}


Fitopatogenicznych Bakterii Instytutu Mikrobiologii i Wirusologii im. D.K. Zabołotnogo Państwowej Akademii Nauk Ukrainy (IMW PANU) (D.K. Zabolotny Institute of Microbiology and Virology of the National Academy of Science of Ukraine - IMVNASU).

Cechy morfologiczne, fizjologiczne i biochemiczne wyizolowanych izolatów bakterii badano metodami opisanymi w pracach Klementa (1963) i Gerhardta (1983). Aktywność oksydazy określono według Kovacsa (1956). Identyfikację wyizolowanych bakterii przeprowadzono przez porównanie ich właściwości z charakterystyką kolekcyjnych szczepów P. agglomerans (BSMB 2005).

\section{Wyniki i dyskusja / Results and discussion}

Objawy choroby przejawiające się porażeniem łodyg u soi w fazie kwitnienia roślin (do 60\% roślin na polach) zaobserwowano po raz pierwszy $w$ kilku regionach Ukrainy w roku 2003 (rys. 1). Z tego powodu zdecydowano się na przeprowadzenie systematycznych badań w wielu doświadczalnych i produkcyjnych uprawach soi położonych w strefie laso-stepowej, w celu identyfikacji patogenu $P$. agglomerans oraz miejsca jego rozprzestrzeniania się wśród innych patogenów bakteryjnych soi jako czynnika chorobotwórczego.

Z uszkodzonych tkanek różnych odmian soi izolowano czyste kultury bakterii, następnie badano ich właściwości chorobotwórcze (tab. 2). Stwierdzono, że występujące $\mathrm{u}$ nich cechy morfologiczne były typowe dla gatunku P. agglomerans, a mianowicie: Gram-ujemne, ruchliwe, asporogeniczne pałeczki tworzące żółte, lekko wypukłe, półprzezroczyste, błyszczące kolonie o gładkiej powierzchni. Wykazano, że zarówno kolekcyjne, jak i wyizolowane w doświadczeniu wirulentne szczepy okazały się wysoko i średnio agresywne dla soi. Izolaty $P$. agglomerans porażały liście i nasiona soi, a większość wyizolowanych szczepów nie traciła swojej wirulentności nawet po dłuższym ich przechowywaniu (tab. 2).

Wykazano również, że badane szczepy nie są zdolne do wytworzenia siarkowodoru, indolu, oksydazy i azotanów, lecz koagulują mleko, rozcieńczają żelatynę i tworzą alkalia na lakmusowej serwatce. Wytypowane przez autorów niniejszej publikacji szczepy bakteryjne, jak i kolekcyjne, wykorzystywały jako jedyne źródło pożywienia szereg alkoholi i cukrów, z wyłączeniem laktozy (tab. 3). W przeciwieństwie do głównego patogenu, jakim jest $X$. axonopodis pv. glycines, bakteria P. agglomerans fermentuje w warunkach anaerobowych glukozę do kwasów. Jest również wysoko aktywna podczas wzrostu na podłożach diagnostycznych, z wyłączeniem laktozy, co jest charakterystyczne dla rodziny Enterobacteriaceae. Przeprowadzona analiza wykazała, że na podstawie stwierdzonych właściwości morfologiczno-kulturowych i biochemicznych, nowo wyizolowane szczepy są typowymi przedstawicielami gatunku $P$. agglomerans.

Obecnie w diagnostyce mikrobiologicznej skład kwasów tłuszczowych lipidów komórkowych uważany jest za ważną chemotaksonomiczną właściwość przy rodzajowej i gatunkowej identyfikacji drobnoustrojów. Stwierdzono znaczną zmienność składu ilościowego, a w niektórych przypadkach i składu jakościowego kwasów tłuszczowych lipidów komórkowych, nowo izolowanych i kolekcyjnych szczepów $P$. agglomerans, co może wskazywać że ten test nie pozwala na skuteczną chemotaksonomiczną identyfikację gatunkową (BMSB 2005; Petrychenko i wsp. 2013). Dlatego określenie przynależności izolatów bakterii $P$. agglomerans do gatunku, powinno być identyfikowane za pomocą zestawu innych cech genotypowych (Hvozdyak i wsp. 2011; Petrychenko i wsp. 2013).

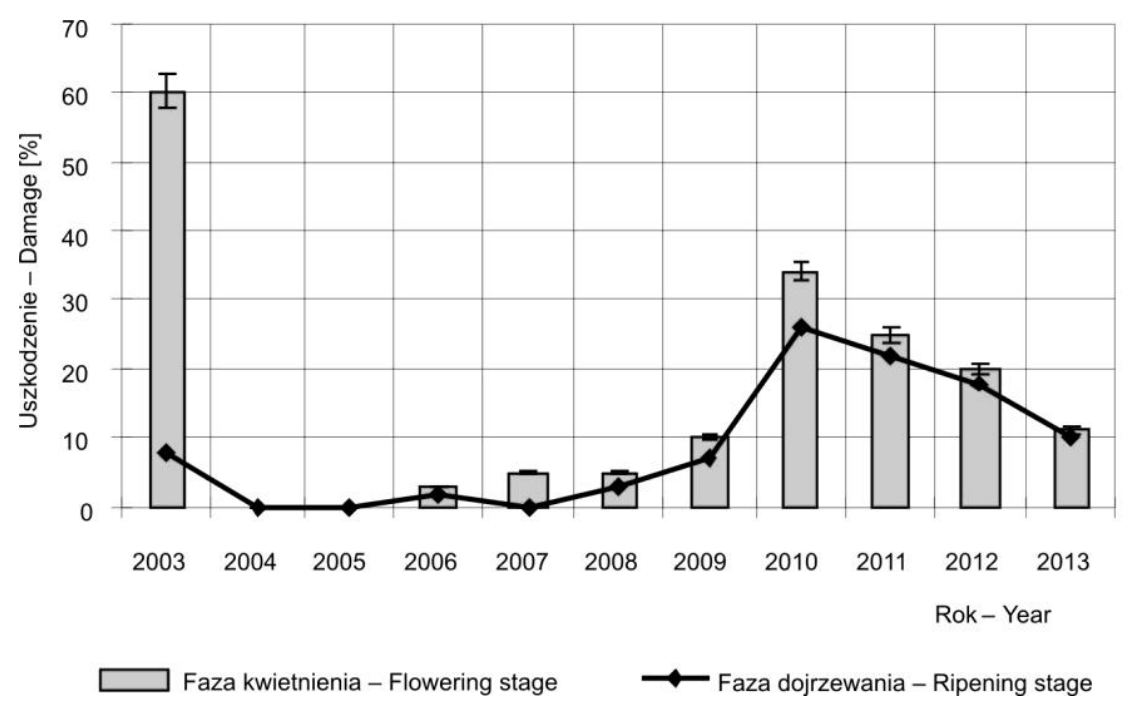

Rys. 1. Porażenie roślin soi przez Pantoea agglomerans w latach 2003-2013

Fig. 1. Infection of soybean crops by Pantoea agglomerans in 2003-2013 
Tabela 2. Wirulentne właściwości wyizolowanych szczepów izolatów gatunku Pantoea agglomerans przy sztucznej inokulacji odmiany soi Kijowska-27

Table 2. Virulent properties of isolated strains type Pantoea agglomerans during artificial inoculation of soybean variety Kyivska-27

\begin{tabular}{|c|c|c|c|}
\hline \multirow{2}{*}{ Izolaty - Isolates } & \multicolumn{3}{|c|}{ Inokulacja - inoculation } \\
\hline & łodyga - stem & liście - leaves & nasiona - seeds \\
\hline \multicolumn{4}{|c|}{2003} \\
\hline 15 szczepów - 15 strains & $3-4$ & - & - \\
\hline 14 szczepów - 14 strains & 3 & \pm & 2 \\
\hline 18 szczepów - 18 strains & $3-4$ & 2 & $2-3$ \\
\hline \multicolumn{4}{|c|}{$2006-2007$} \\
\hline 12 szczepów - 12 strains & $3-4$ & \pm & \pm \\
\hline \multicolumn{4}{|c|}{$2008-2009$} \\
\hline 12 szczepów - 12 strains & $3-4$ & - & - \\
\hline 10 szczepów - 10 strains & $3-4$ & \pm & \pm \\
\hline 27 szczepów - 27 strains & $3-4$ & $2+$ & $2-3$ \\
\hline \multicolumn{4}{|c|}{2010} \\
\hline 25 szczepów - 25 strains & $3-4$ & 2 & 2 \\
\hline 17 szczepów - 17 strains & $3-4$ & 2 & $2-3$ \\
\hline \multicolumn{4}{|c|}{$2011-2012$} \\
\hline 12 szczepów - 12 strains & $3-4$ & 2 & 2 \\
\hline 8 szczepów -8 strains & $3-4$ & + & \pm \\
\hline \multicolumn{4}{|c|}{2013} \\
\hline 15 szczepów - 15 strains & $3-4$ & + & 2 \\
\hline
\end{tabular}

Ocena agresywności przedstawiona w 5-punktowej skali (0:4), 0 - brak infekcji, 4 - porażenie największe

The evaluation of the aggressiveness presented in a 5-point scale (0:4), 0 - no infection, all plants disease free, 4 - severe plant infection

Tabela 3. Fizjologiczno-morfologiczne i biochemiczne właściwości izolatów Pantoea agglomerans

Table 3. Physiological, morphological and biochemical properties of the isolates of Pantoea agglomerans

\begin{tabular}{|c|c|c|}
\hline \multirow[b]{2}{*}{$\begin{array}{l}\text { Właściwości fizjologiczno-biochemiczne } \\
\text { Physiological and biochemical properties }\end{array}$} & \multicolumn{2}{|c|}{ Izolaty - Isolates } \\
\hline & $\begin{array}{c}\text { kolekcyjne szczepy B-1089 }{ }^{\mathrm{T}}, 8490, \\
7695,8456,8508 \text { i szczepy typu Pantoea } \\
\text { agglomerans collection strains B-1089 } 108490, \\
7695,8456,8508 \text { and strains type } \\
\text { Pantoea agglomerans }\end{array}$ & $\begin{array}{l}\text { szczepy Xanthomonas axonopodis } \\
\text { pv. glycines } 3,8562,9075 \\
\text { strains Xanthomonas axonopodis } \\
\text { pv. glycines } 3,8562,9075\end{array}$ \\
\hline 1 & 2 & 3 \\
\hline Ruchliwość - Motylity & + & + \\
\hline $\begin{array}{l}\text { Barwienie metodą Grama - Gamma } \\
\text { staining }\end{array}$ & - & - \\
\hline Oksydaza - Oxidase & - & - \\
\hline Redukcja mitratów - Nitrates reduction & - & - \\
\hline Lakmusowa syrow - Lit mus test & A & $\mathrm{K}$ \\
\hline Wykorzystanie mleka - Milk use & $\mathrm{Z}$ & $\mathrm{Z} / \mathrm{P}$ \\
\hline Powstawanie $\mathrm{H}_{2} \mathrm{~S}$ - Formation of $\mathrm{H}_{2} \mathrm{~S}$ & - & + \\
\hline Hydroliza żelatyny - Hydrolysis of gelatin & + & - \\
\hline \multicolumn{3}{|l|}{ Wykorzystanie: - Use of: } \\
\hline $\begin{array}{l}\text { Glukozy w warunkach tlenowych } \\
\text { Glucose in anaerobic conditions }\end{array}$ & $\mathrm{K}$ & $-1+$ \\
\hline $\begin{array}{l}\text { Glukozy w warunkach beztlenowych } \\
\text { Glucose in aerobic conditions }\end{array}$ & $\mathrm{K}$ & - \\
\hline
\end{tabular}




\begin{tabular}{l|c|c}
\hline \multicolumn{1}{c|}{1} & 2 & 3 \\
\hline Sacharozy - Saccharose & $\mathrm{K}$ & $\mathrm{K}$ \\
\hline Laktozy - Lactose & - & $\mathrm{K}$ \\
\hline Maltozy - Maltose & $\mathrm{K}$ & $\mathrm{K}$ \\
\hline Ramnozy - Ramnose & $\mathrm{K}$ & $-/ \mathrm{K}$ \\
\hline Galaktozy - Galactose & $\mathrm{K}$ & $\mathrm{K}$ \\
\hline Arabinozy - Arabinose & $\mathrm{K}$ & $\mathrm{K}$ \\
\hline Ksylozy - Xylosis & $\mathrm{K}$ & $-/ \mathrm{K}$ \\
\hline Mannitol - Mannitol & $\mathrm{K}$ & - \\
\hline Dulcitol - Dulcitol & - & żółty - yellow \\
\hline Pigment - Pigment & żółty - yellow & \\
\hline
\end{tabular}

- brak oznak, $\mathrm{P}$ - peptonizacja, Z - krzepnięcie, $\mathrm{K}$ - powstanie kwasu, A - powstanie alkalia

- no signs, $\mathrm{P}$ - peptonization, $\mathrm{Z}$ - coagulation, $\mathrm{K}$ - acid formation, $\mathrm{A}$ - creation of alkali

Przeprowadzona w niniejszej pracy systematyczna kontrola postępu procesu zakażenia podczas okresu wegetacji pozwoliła na określenie ogólnych wzorców rozprzestrzeniania się patogenu porażającego łodygi soi w zależności od fazy rozwoju rośliny. Stwierdzono, że w okresie do kwitnienia, na ogonkach, żyłkach liści i łodyg występowały na badanych roślinach brązowe lub czarne podłużne plamy i krótkie smugi. W fazie kwitnienia, formowania się strąków i początku wypełnienia nasion obserwowano na dolnej części łodygi czerwonobrązowe, fioletowe, czasami mokre, wydłużone plamy i paski, natomiast od początku nalewania ziarna do końca dojrzewania powszechnie występowały nekrotyczne, podłużne, czarnobrązowe paski na całej łodydze.

$P$. agglomerans porażał głównie łodygi roślin. Intensywne porażenie roślin soi przez $P$. agglomerans bywa opóźnione przez rozwój populacji innych, wysoko szkodliwych patogenów bakteriozy soi (Gerhardt 1983), co może być wykorzystywane do biokontroli (Vanneste i Beer 1992; Volksch i wsp. 1996).

Podczas wczesnych etapów rozwoju procesów zakażenia soi najbardziej rozpowszechnione są patogeny bakteriozy soi: P. savastanoi pv. glycinea (kątowa plamistość), $X$. axonopodis pv. glycines (bakterioza pustułkowa) oraz $P$. agglomerans wywołujące bardzo podobne objawy chorobowe, tj. bardzo drobne, czarnobrązowe plamy i suche, brązowoczekoladowe lub czerwonawe krótkie przebarwienia (3-4 mm) (Shkalykov i wsp. 2004). W pewnych fazach rozwoju choroby pojawia się wiele podobnych objawów porażenia pochodzących od różnych patogenów. W naturalnych warunkach, w niektórych przypadkach, objawy choroby mogą być maskowane działaniem czynników biotycznych i abiotycznych.
W ciągu okresu badawczego z założonych i produkcyjnych upraw soi wyodrębniono 185 szczepów $P$. agglomerans, które powodowały porażenie ich łodyg. Jak wynika z rysunku 1., w okresie przeprowadzonych badań (lata 2003-2013), na wyznaczonych obiektach doświadczalnych w 2003 roku stwierdzono znaczny wzrost porażenia łodyg soi patogenem $P$. agglomerans, po czym w okresie od 2004-2005 roku nastapił całkowity zanik ich porażenia. Ponowne, stopniowe wystąpienie objawów zakażenia łodyg soi zaobserwowano od 2006-2010 roku ze szczytem rozwoju choroby w 2010 roku. W latach 20112013 stwierdzono ponowny zanik choroby. Prawdopodobnie takie wahania związane są z gwałtownymi zmianami temperatury i wilgotności powietrza oraz stosowaniem różnorodnych pestycydów.

Powyższe obserwacje mogą zostać wykorzystane do przewidywania rozprzestrzeniania się badanego patogenu w uprawach soi.

\section{Wnioski / Conclusions}

1. Na plantacjach soi na Ukrainie stwierdzono występowanie fakultatywnego fitopatogenu $P$. agglomerans.

2. W poszczególnych latach porażenie roślin przez $P$. agglomerans było zróżnicowane. W początkowym okresie badań zaobserwowano spadek uszkodzenia roślin przez $P$. agglomerans, a następnie umiarkowany wzrost liczby porażonych roślin.

3. Ze względu na podobieństwo objawów do chorób powodowanych przez inne pasożyty bakteryjne i grzybowe, dla potwierdzenia prawidłowej identyfikacji $P$. $a g$ glomerans konieczne są badania laboratoryjne.

\section{Literatura / References}

Bergey's Mannual of Systematic Bacteriology (BMSB). 2005. Vol. 2: The Proteobacteria (G. Garrity, D.J. Brenner, N.R. Krieg, J.R. Stanley, eds.). 2nd ed. Springer, N.Y., 1388 pp.

Dankevich L.A., Zytkevych N.V., Patyka V.F. 2010. Identifikacija patogiennyh dla soi sztammow Pantoea agglomerans s pomoszczju żirnokislotnogo sostawa kletok. W: Matieriały VII Mieżdunarodnoj Konferencii, Sowriemiennoie sostoianiie i perspiektiwy razwitija mikrobiologii i biotechnologii. Białoruś, Mińsk, 31.05-04.06.2010: 21-23. 
Gerhardt D.T. 1983. Mietody obszczej baktieriologii. Mir, Moskwa, 563 pp.

Gorlenko M.V. 1966. Baktierialnyie boliezni rastienij. Wyższa Szkoła, Moskwa, 300 pp.

Hvozdyak R.I., Pasichnik L.A., Yakovleva L.M., Moroz S.M., Lytvynchuk O.O., Zhytkevych N.V., Hodos S.F., Butsenko L.M., Dankevich L.A., Grynyk I.V., Patyka V.P. 2011. Fitopatogienni baktierii. Baktierialni chworobi roslin. NPP Interserwis, Kyjiw, 444 pp.

Iwanow A.V. 2001. Baktierialnyie zaboliewanija łuka i czesnoka w Riespublikie Moldowa i razrabotka schiemy otbora ustojcziwych $\mathrm{k}$ nim form. Awtoreferat disertacji na soiskanie stepieni kandidata biologicieskich nauk. Moskwa, $16 \mathrm{pp}$.

Klement Z. 1963. Rapid detection pathogenicity of phytopathogenic Pseudomonas. Journal Nature 199 (4890): 299-300.

Kovacs N. 1956. Identification of Pseudomonas pyocyanea by the oxidase reaction. Journal Nature 178, p. 703.

Patyka V.P., Omelyanets T.G., Grynyk I.V., Petrychenko V.F. 2007. Ekologija mikroorganizmiw. Osnowa, Kijów, 186 pp.

Petrychenko V.F., Kornijchuk O.V., Pasichnik L.A., Butsenko L.M., Zhytkevych N.V., Hnatiuk T.T., Patyka V.P. 2013. Baktierialni chworobi silskogospodarskich roslin i piesticidi. Wisnik agrarnoi nauki 4 (13): 21-26.

Shkalykov V.A., Bukreev D.D., Gorbaczev I.V. 2004. Zaszczita rastienij ot boleznej. Kolos, Moskwa, 255 pp.

Vanneste J.L., Beer S.V. 1992. Role of antibiotic production by Erwinia herbicola Eh 252 in biological control of Erwinia amylovora. Journal of Bacteriology 174 (9): 2785-2786.

Volksch B., Nuske J., May R. 1996. Characterization of two epiphytic bacteria from soybean leaves with antagonistic activities against Pseudomonas syringae pv. glycinea. Journal of Basic Microbiology 36 (6): 453-462.

Zhytkevych N.V., Gnatiuk T.T., Petrychenko V.F., Patyka V.P. 2009. Diagnostika baktierialnich patogieniw soi. Miżwidomczij tiematicznij naukowij zbirnik: Kormi i Kormowirobnictvo 64: 62-69.

Zhytkevych N.V., Zhmurko L.G. 2005. Rozpowsiudszczenija baktierialnich zachworjuwan soi u Kniwskij obłasti. Visnik Odeskogo Nacionalnogo Universitetu 10 (7): 244-248. 